\title{
Living near the port area is associated with physical inactivity and sedentary behavior
}

\author{
Morar perto da área portuária está associado à inatividade física e \\ comportamento sedentário
}

\author{
Evandro Fornias Sperandio', Rodolfo Leite Arantes", Tsai Ping Chao"', Marcello Romiti", Antônio Ricardo de Toledo Gagliardi", \\ Victor Zuniga Dourado'v
}

Laboratory of Epidemiology and Human Movement (Epidemiologia e Movimento Humano, EPIMOV), Universidade Federal de São

Paulo, Santos (SP), Brazil

\begin{abstract}
IPT, PhD. Associate Researcher, Department of Human Movement Sciences, Universidade Federal de São Paulo (Unifesp), Santos (SP), Brazil. "MD, PhD. Researcher, Department of Cardiovascular Medicine, Angiocorpore Institute of Cardiovascular Medicine, Santos (SP), Brazil. '"PT. Specialization Student, Instituto do Coração (InCor), São Paulo (SP), Brazil.

nPT, PhD. Associate Professor, Department of Human Movement Sciences, Universidade Federal de São Paulo (Unifesp), Santos (SP), Brazil. Visiting Scholar, Bernard Lown Scholars in Cardiovascular Health Program, Harvard T.H. Chan School of Public Health, Boston, United States.
\end{abstract}

\section{KEY WORDS:}

Environmental health.

Motor activity.

Sedentary lifestyle.

Social class.

Risk factors.

\section{PALAVRAS-CHAVE:}

Saúde ambiental.

Atividade motora.

Estilo de vida sedentário

Classe social.

Fatores de risco.

\begin{abstract}
CONTEXT AND OBJECTIVE: The impact of the port of Santos, Brazil, on the population's health is unknown. We aimed to evaluate the association between living near the port area and physical inactivity and sedentary behavior.
\end{abstract}

DESIGN AND SETTING: Cross-sectional study developed at a university laboratory and a diagnostic clinic. METHODS: 553 healthy adults were selected and their level of physical activity in daily life was assessed using accelerometers. Multiple linear and logistic regressions were performed using physical inactivity and sedentary behavior as the outcomes and living near the port area as the main risk factor, with adjustments for the main confounders.

RESULTS: Among all the participants, 15\% were resident near the port area. They took 699 steps/day and presented, weekly, $2.4 \%$ more sedentary physical activity, $2.0 \%$ less time in standing position and $0.9 \%$ more time lying down than residents of other regions. Additionally, living near the port area increased the risk of physical inactivity by 2.50 times and the risk of higher amounts of sedentary behavior ( $\geq 10$ hours/day) by 1.32 times.

CONCLUSION: Living near the port of Santos is associated with physical inactivity and higher sedentary behavior among adults, regardless of confounders. The reasons for this association should be investigated in longitudinal studies.

\section{RESUMO}

CONTEXTO E OBJETIVOS: O impacto do porto de Santos, no Brasil, sobre a saúde da população é desconhecido. Nosso objetivo foi avaliar a associação entre viver nas proximidades da área portuária e a inatividade física e comportamento sedentário.

TIPO DE ESTUDO E LOCAL: Estudo transversal desenvolvido em laboratório universitário e em uma clínica de diagnósticos.

MÉTODOS: Foram selecionados 553 adultos saudáveis e seu nível de atividade física na vida diária foi avaliado usando acelerômetros. Foi realizada regressão linear múltipla e logística usando a inatividade física e o comportamento sedentário como desfechos e morar perto da área portuária como o fator de risco principal, ajustando para os principais confundidores.

RESULTADOS: Entre todos os participantes, 15\% residiam na área portuária. Estes deram 699 passos/dia a menos e apresentaram, por semana, 2,4\% da atividade física mais sedentária, 2,0\% menos tempo em pé e passaram 0,9\% mais tempo deitados do que os residentes das demais regiões. Além disso, morar nas proximidades da área portuária aumentou o risco de inatividade física em 2,5 vezes, assim como o risco de maior comportamento sedentário ( $\geq 10$ horas/dia) em 1,32 vezes.

CONCLUSÃO: Morar perto do porto de Santos tem associação com a inatividade física, assim como o aumento do comportamento sedentário em adultos, independentemente de fatores de confusão. As razões para tal associação devem ser investigadas em estudos longitudinais. 


\section{INTRODUCTION}

Historically, ports are considered to be engines of economic development for the cities and regions where they are located. The port of Santos in Brazil is one of the most important ports in Latin America due to its size and export capacity. ${ }^{1}$ This is the main gateway for incoming and outgoing products in this country. Despite boosting the economy, it is known that ports cause a negative impact on the health of residents of the surrounding areas. ${ }^{2}$ Living near the port area is associated with low socioeconomic status, ${ }^{3}$ and the pollution of the port increases the risk of developing respiratory ${ }^{4}$ and cardiovascular disease. ${ }^{5}$

According to the global recommendations on physical activity for health, "adults aged 18-64 should do at least 150 minutes of moderate-intensity aerobic physical activity throughout the week or do at least 75 minutes of vigorous-intensity aerobic physical activity throughout the week or an equivalent combination of moderate and vigorous-intensity activity." 6 Thus, physical inactivity is characterized as failure to reach the recommendations mentioned above. ${ }^{7}$ Sedentary behavior, in turn, can be defined as "any wakeful behavior characterized by energy expenditure of 1.5 or fewer metabolic equivalent tasks (METs) while in a sitting or reclining posture". It is well known that physical inactivity is related to health impairments, but sedentary behavior has recently emerged as a new independent risk factor for chronic diseases as well as for mortality, regardless of moderate-to-vigorous physical activity. ${ }^{9-14}$ Examples of sedentary behavior include watching television, sitting, playing video games and using computers. ${ }^{15}$ Current studies have been investigating associations of physical activity and sedentary behaviors separately or combined.

Our previous results showed that the proportion of physically inactive subjects in a sample in the city of Santos was between $14 \%$ and $20 \%$ and that there was an association between physical inactivity and restrictive lung patterns detected by spirometry. ${ }^{16,17}$ The level of physical activity in daily life is influenced by the physical environment in which subjects live, with their social and individual correlates, ${ }^{18}$ but may also be related to chronic exposure to air pollutants. The vicinity of the port area in Santos seems to be a violent area with few or no safe public spaces where people can perform physical activities. Moreover, it is a highly polluted area, where the annual average levels of particulate matter grossly exceed what is recommended by the World Health Organization. ${ }^{19}$

Information about the impact of the port of Santos on the population's health is scarce, especially in relation to the level of physical activity within daily life and sedentary behavior directly evaluated by means of triaxial accelerometers. Our hypothesis was that living in neighborhoods close to the port of Santos would be associated with higher prevalence of physical inactivity and increased levels of sedentary behavior, regardless of the main confounders.

\section{OBJECTIVE}

We aimed to evaluate the association between living near the port of Santos and physical inactivity and sedentary behaviors among adults.

\section{METHODS}

\section{Participants and design}

Five hundred and fifty-three adults ( $\geq 20$ years of age) were selected from the Epidemiology and Human Movement Study, i.e. the EPIMOV (Estudo Epidemiológico sobre o Movimento Humano) study. Briefly, the EPIMOV study is an ongoing cohort study with the primary objective of investigating the longitudinal association of sedentary behaviors and physical inactivity with occurrences of hypokinetic diseases, especially cardiorespiratory and musculoskeletal diseases. The present study is a cross-sectional study from the first year of the EPIMOV study. The volunteers who participated in it were recruited through publicity in social networks, folders displayed in the universities of the region, local magazines and newspapers.

We divided the participants into two groups: people residing near the port area and people residing in other surrounding neighborhoods within the metropolitan area of Santos. We used the map of the city to select residents of neighborhoods that are adjacent to the port area. We defined the participants' socioeconomic level according to the mean income of each neighborhood based on official documents held by the city of Santos, which include a map of the city according to the average income of heads of households. The participants were divided into three monthly income levels (i.e. low: $\mathrm{R} \$ 622-1866$; moderate: $\mathrm{R} \$ 1866-3732$; and high: $\mathrm{R} \$ 3732-6220$ ).

In the early clinical evaluation, personal and demographic data were collected. In addition, the participants answered the physical activity readiness questionnaire ${ }^{20}$ in order to evaluate some possible risks relating to performing physical exercises such as cardiopulmonary exercise testing. They also answered questions about any history of respiratory illness, based on the American Thoracic Society questionnaire, ${ }^{21}$ to investigate exposure to pollutants, history of asthma and smoking status; and cardiovascular disease risk stratification was performed as specified by the American College of Sports Medicine. ${ }^{22}$

We excluded participants with a self-reported diagnosis of heart disease, lung disease or musculoskeletal disorders. We made objective measurements to evaluate physical activity in daily life through triaxial accelerometry and lung function through spirometry; and conducted cardiopulmonary exercise testing using a ramp protocol on a treadmill. We also investigated the presence of self-reported major risk factors for cardiovascular disease, including age ( $\geq 45$ years for males and $\geq 55$ years for females), systemic arterial hypertension, diabetes/hyperglycemia, dyslipidemia/hypercholesterolemia, current cigarette smoking and family history of premature coronary heart disease. A family history of premature 
coronary heart disease was defined as myocardial infarction or sudden death of father or other male first-degree relative before 55 years of age, or of mother or other female first-degree relative before 65 years of age. Education level was reported as illiterate or completed primary, secondary or tertiary education.

Smoking was also investigated through self-reporting. The subjects were considered to be smokers if they reported current tobacco use and had smoked 100 or more cigarettes during their lifetime. ${ }^{23}$

The participants were informed about the possible risks and discomforts of this study and signed a consent form. The local Ethics Committee for Human Research approved this study (protocol: 186.796).

\section{Anthropometric measurements}

Body weight and height were measured, and the body mass index was calculated in accordance with standardized methods. ${ }^{24}$

\section{Spirometry}

Spirometry was performed using a handheld spirometer (Quark PFT/CPET, Cosmed, Pavona di Albano, Italy) in accordance with the criteria established by the American Thoracic Society. ${ }^{25}$ The forced expiratory volume in the first second $\left(\mathrm{FEV}_{1}\right)$, forced vital capacity (FVC) and $\mathrm{FEV}_{1} / \mathrm{FVC}$ ratio were quantified. The predicted values were calculated using national reference equations. ${ }^{26}$

\section{Cardiorespiratory fitness}

The maximum/symptom-limited exercise capacity was assessed during cardiopulmonary exercise testing on a treadmill (ATL, Inbrasport, Curitiba, Brazil), following a ramp protocol. After 3 minutes at rest, the speed and inclination were automatically incremented according to the estimated maximal oxygen consumption ( $\left.\mathrm{V}^{\prime} \mathrm{O}_{2} \mathrm{max}\right)$, with the aim of completing the test in about 10 minutes. ${ }^{27,28}$ Cardiovascular, ventilatory and metabolic variables were analyzed breath by breath, using a gas analyzer (Quark PFT, Cosmed, Pavona di Albano, Italy). Oxygen uptake $\left(\mathrm{V}^{\prime} \mathrm{O}_{2}\right)$, carbon dioxide production $\left(\mathrm{V}^{\prime} \mathrm{CO}_{2}\right)$, minute ventilation (V'E), and heart rate were monitored throughout the test. The data were filtered every 15 seconds for further analysis. Peak $\mathrm{V}^{\prime} \mathrm{O}_{2}$ was defined as the arithmetic average of the last 15 seconds at the end of the incremental phase of the cardiopulmonary exercise testing.

\section{Accelerometer-based sedentary behavior and physical activity in daily life}

Sedentary behavior and physical activity in daily life were evaluated using a previously validated triaxial accelerometer (ActiGraph GT3X+, MTI, Pensacola, FL, USA). ${ }^{29-31}$ The equipment consisted of a small, lightweight box $(4.6 \mathrm{~cm} \times 3.3 \mathrm{~cm} \mathrm{x} 1.5 \mathrm{~cm})$ that was attached to the waist above the dominant hip, by means of a band (total weight $=19 \mathrm{~g}$ ). It had the capacity to measure human movement along the vertical, sagittal and mediolateral axes. The participants were subjected to seven consecutive days of evaluation during their wakeful hours. To be considered valid, data collection days needed to have at least 10 hours of continuous monitoring, starting when the subject woke up, together with absence of excessive counts $(>20,000)$. We instructed the participants to remove the accelerometer at bedtime and during showers and aquatic activities.

Periods with fewer than 60 counts per minutes (cpm) on the accelerometer were interpreted as periods when the accelerometer was not worn, with a tolerance of 2 minutes for periods with some movement, i.e. less than $50 \mathrm{cpm}$. The thresholds for the intensity of the physical activity were as follows: ${ }^{32} 1$. very light $(100-759 \mathrm{cpm})$; 2. light (760-1951 cpm); and 3. moderate-to-vigorous (> $1951 \mathrm{cpm})$. The minimum quantity and intensity levels for physical activity to be considered as such was 150 minutes of moderate-to-vigorous physical activity per week. ${ }^{33,34}$ Individuals who did not reach this level of physical activity were considered to be physically inactive.

The total amount of sedentary behavior was determined based on the number of minutes with counts less than 100. On the other hand, active time was considered to be time spent on activities with $\geq 100 \mathrm{cpm}$. By means of the inclinometer located inside the accelerometer, the time spent in each body position was measured (i.e. reclining during wakeful hours, sitting or standing). The measurements were calculated as minutes/week and as percentages of the total time. Sedentary behavior was also assessed as a categorical variable in accordance with the threshold recently described. ${ }^{13,14}$ Participants who performed $\geq 10$ hours/day of sedentary activities were classified in a group with a high amount of sedentary behavior, whereas the group with a low amount was defined as $<10$ hours/ day of such activities. Only data from the participants who used the accelerometer for at least four valid days were analyzed.

\section{Statistical analysis}

The sample size was calculated in accordance with the prevalence of physical inactivity of around $20 \%$ that was observed in previous findings from the EPIMOV study in the metropolitan area of the city of Santos. ${ }^{16}$ Through taking a $99 \%$ confidence interval, it was found that at least 423 participants needed to be enrolled in the present study. We performed the sample size calculation using the free tools available on the website www.openepi.com.

Our first statistical analysis was a descriptive analysis of the data. We then evaluated whether being a resident in the port area was associated with physical inactivity in daily life and sedentary behavior, by means of multiple linear regression, regardless of socioeconomic and educational level. We developed two multiple logistic regression models in which physical inactivity and sedentary behavior were taken to be the outcomes and living near the port area was the main exposure. Adjusted odds ratios and $95 \%$ confidence intervals were calculated. Both multiple logistic regressions were adjusted according to the following: age; sex; 
race (i.e. categorized as black, white, mixed, Amerindian or East Asian); education level (i.e. classified as tertiary educational attainment or not); self-reported cardiovascular disease risk factors (i.e. hypertension, diabetes, dyslipidemia, smoking, obesity or physical inactivity); cardiorespiratory fitness (peak $\mathrm{V}^{\prime} \mathrm{O}_{2}[\mathrm{ml} / \mathrm{min} / \mathrm{kg}]$ )]; and lung function $\left(\mathrm{FEV}_{1}[\right.$ liters] $)$. Obesity was categorized as yes or no (body mass index $\geq 30$ or $<30 \mathrm{~kg} / \mathrm{m}^{2}$, respectively). The probability of alpha error was set at $5 \%$.

\section{RESULTS}

Fifteen percent $(n=83)$ of our participants were residents in the port area. These were significantly younger and had higher socioeconomic status (Table 1). However, the univariate analysis showed that sex, race, anthropometry, lung function, exercise capacity, smoking status, physical inactivity and risk of cardiovascular

Table 1. General characteristics of the sample

\begin{tabular}{|c|c|c|}
\hline & $\begin{array}{l}\text { Residents in } \\
\text { port area } \\
(n=83)\end{array}$ & $\begin{array}{l}\text { People who did } \\
\text { not live in port } \\
\text { area }(n=470)\end{array}$ \\
\hline Age (years)* & $41 \pm 12$ & $45 \pm 14$ \\
\hline Sex (\%, male/female) & $44 / 56$ & $36 / 64$ \\
\hline \multicolumn{3}{|l|}{ Race (\%) } \\
\hline White & 66.2 & 73.7 \\
\hline Black & 6.0 & 4.6 \\
\hline Mixed & 22.2 & 19.4 \\
\hline East Asian & 5.6 & 1.0 \\
\hline Amerindian & 0 & 1.3 \\
\hline Weight (kg) & $75 \pm 19$ & $76 \pm 16$ \\
\hline Height (m) & $1.64 \pm 0.11$ & $1.63 \pm 0.09$ \\
\hline Body mass index $\left(\mathrm{kg} / \mathrm{m}^{2}\right)$ & $27 \pm 6$ & $28 \pm 5$ \\
\hline FVC (liters) & $3.89 \pm 1.16$ & $3.56 \pm 1.03$ \\
\hline FVC (\% pred.) & $97 \pm 11$ & $94 \pm 13$ \\
\hline $\mathrm{FEV}_{1}$ (liters) & $3.19 \pm 0.97$ & $2.89 \pm 0.84$ \\
\hline $\mathrm{FEV}_{1}$ (\% pred.) & $96 \pm 12$ & $93 \pm 13$ \\
\hline $\mathrm{FEV}_{1} / \mathrm{FVC}(\%)$ & $82 \pm 5$ & $81 \pm 5$ \\
\hline Peak V'O ${ }_{2}(\mathrm{ml} / \mathrm{min} / \mathrm{kg})$ & $34 \pm 11$ & $29 \pm 10$ \\
\hline $\begin{array}{l}\text { Completed secondary } \\
\text { educational level (\%) }\end{array}$ & 42.3 & 50.8 \\
\hline \multicolumn{3}{|l|}{ Socioeconomic level (\%) } \\
\hline Low income* & 13.2 & 35.6 \\
\hline Moderate income & 43.3 & 34.2 \\
\hline High income* & 43.3 & 18.4 \\
\hline \multicolumn{3}{|l|}{ Cardiovascular risk (\%) } \\
\hline $\begin{array}{l}\text { Systemic arterial } \\
\text { hypertension }\end{array}$ & 12.5 & 18.2 \\
\hline Diabetes mellitus & 8.3 & 11.2 \\
\hline Dyslipidemia & 23.6 & 28.8 \\
\hline Obesity & 29.2 & 36.3 \\
\hline Smoking & 6.9 & 11.3 \\
\hline Physical inactivity ${ }^{\dagger}$ & 20.8 & 21.9 \\
\hline
\end{tabular}

Data presented as mean \pm standard deviation or as count and percentage. ${ }^{*} P<0.05$ : residents of the port area versus residents of other neighborhoods; ${ }^{\dagger}$ Assessed using triaxial accelerometers. $F V C=$ forced vital capacity; $F E V_{1}=$ forced expiratory volume in the first second; $\mathrm{V}^{\prime} \mathrm{O}_{2}=$ oxygen uptake. disease variables were not statistically different between residents and non-residents in the vicinity of the port. The prevalences of diabetes mellitus, hypertension and dyslipidemia in this study were similar to those found in population-based studies in Brazil.

The results from the linear multiple regression analysis showed that there was an association between living near the port area and increased sedentary behavior, as evaluated using triaxial accelerometers. Other variables such as socioeconomic status, education level and smoking were also significant determinants of higher amounts of sedentary behavior (Table 2). Living in the port area increased the risk of physical inactivity more than twofold, independently of any other confounder. Age and smoking also increased the risk of physical inactivity, after adjusting the logistic regression model according to age, gender, education level, socioeconomic status, risk factors for cardiovascular disease, cardiorespiratory fitness, lung function and smoking. On the other hand, cardiorespiratory fitness reduced the risk of physical inactivity (Table 3 ).

Regarding sedentary behavior, $51.7 \%$ of our participants performed $\geq 10 \mathrm{~h} /$ day of sedentary activities. Living near the port increased the risk of high amounts of sedentary behavior by $32 \%$. In this multiple logistic regression model, age, gender, socioeconomic status, education level and smoking were also selected as determinants of high amounts of sedentary behavior. There was a positive association between higher socioeconomic status and higher amounts of sedentary behavior (Table 4).

Through multiple regression analysis, the residents of the port area showed higher amounts of sedentary behavior, i.e. less time standing and more time reclining, and also a lower number of steps/day, in comparison with people who did not live in the port area (Table 5).

\section{DISCUSSION}

This study investigated the association between living near the largest port in Latin America and physical inactivity and sedentary behavior among adults. The associations found indicated that living near the port of Santos increased the risk of physical inactivity and sedentary behavior among adults, regardless of socioeconomic status, education level, cardiovascular risk, lung function or cardiorespiratory fitness.

Unlike what we expected, the residents of the port area were younger and had higher socioeconomic status than people who did not live in the port area. These results contrast with previously published data. Grobar ${ }^{3}$ observed that the unemployment and poverty rates are significantly higher in port districts. This disparity is possibly due to a peculiarity of the city of Santos. The neighborhood of Ponta da Praia, one of the neighborhoods with the highest average income of the city, is located very close to one of the main terminals of the port. Nevertheless, living near the port region increased the risk of physical inactivity and sedentary behavior, regardless of the higher socioeconomic status of 
the residents of Ponta da Praia. This finding is interesting because studies have shown that low socioeconomic status groups perform an insufficient amount of physical activity to achieve health benefits. ${ }^{35}$ Our results suggest that living next to a major port could affect lifestyle, even among people with privileged socioeconomic status in relation to Brazilian patterns. Therefore, whether living in the port area in Santos is different from living in another port area elsewhere in the world remains to be clarified.

Although there was no association between socioeconomic status and physical inactivity, we observed a positive association

Table 2. Results from linear multiple regression analysis on the association between sedentary behavior evaluated using accelerometers and living in the port area

\begin{tabular}{|c|c|c|c|c|}
\hline Outcome & Living in port area, beta $(95 \% \mathrm{CI})$ & $\mathbf{P}$ & Other significant exposures & $\mathbf{R}^{2}$ \\
\hline Sedentary physical activity (hours/week) & $13.2(2.4-24.0)$ & 0.045 & - & 0.024 \\
\hline Sedentary physical activity (\%/week) & $2.4(1.1-3.7)$ & 0.003 & $\begin{array}{c}\text { Education level } \\
\text { Socioeconomic status } \\
\text { Smoking } \\
\text { Peak V'O }{ }_{2}\end{array}$ & 0.067 \\
\hline Time standing (hours/week) & $-4.4(-7.0--1.8)$ & 0.006 & $\begin{array}{c}\text { Education level } \\
\text { Socioeconomic status } \\
\text { Hypertension } \\
\text { Obesity }\end{array}$ & 0.157 \\
\hline Time standing (\%/week) & $-2.0(-3.3--0.7)$ & 0.014 & $\begin{array}{c}\text { Education level } \\
\text { Socioeconomic status } \\
\text { Hypertension } \\
\text { Obesity }\end{array}$ & 0.180 \\
\hline Time reclining (hours/week) & $1.5(0.2-2.8)$ & 0.074 & $\begin{array}{l}\text { Smoking } \\
\text { Peak V'O }\end{array}$ & 0.068 \\
\hline Time reclining (\%) & $0.9(0.3-1.2)$ & 0.051 & Smoking & 0.055 \\
\hline Average number of steps/day & $-699.1(165.5-1232.7)$ & 0.031 & $\begin{array}{c}\text { Smoking } \\
\text { Obesity } \\
\text { Peak V'O } 2\end{array}$ & 0.079 \\
\hline
\end{tabular}

$\mathrm{Cl}=$ confidence interval. Models adjusted for age, gender, education level, socioeconomic status, hypertension, diabetes mellitus, dyslipidemia, obesity, cardiorespiratory fitness, lung function and smoking.

Table 3. Results from the logistic regression analysis between physical inactivity assessed using accelerometers and factors associated to it (exposures)

\begin{tabular}{|c|c|c|c|c|}
\hline \multirow{2}{*}{ Exposures } & \multirow{2}{*}{$\begin{array}{l}\text { Odds } \\
\text { ratio }\end{array}$} & \multicolumn{2}{|c|}{$95 \%$ confidence interval } & \multirow{2}{*}{$\mathbf{P}$} \\
\hline & & Lower limit & Upper limit & \\
\hline Living in port area & 2.50 & 1.40 & 4.47 & 0.002 \\
\hline Age (years) & 1.03 & 1.01 & 1.04 & 0.000 \\
\hline Sex (male) & 0.69 & 0.48 & 1.007 & 0.055 \\
\hline \multicolumn{5}{|l|}{ Socioeconomic status } \\
\hline Low income & 1 & & & \\
\hline Moderate income & 1.05 & 0.67 & 1.66 & 0.815 \\
\hline High income & 1.12 & 0.68 & 1.84 & 0.648 \\
\hline $\begin{array}{l}\text { Completed secondary } \\
\text { educational level }\end{array}$ & 1.04 & 0.70 & 1.54 & 0.837 \\
\hline Hypertension & 0.78 & 0.49 & 1.25 & 0.313 \\
\hline Diabetes mellitus & 1.04 & 0.60 & 1.81 & 0.868 \\
\hline Dyslipidemia & 0.85 & 0.57 & 1.26 & 0.423 \\
\hline Obesity & 0.97 & 0.67 & 1.41 & 0.979 \\
\hline Smoking & 1.87 & 1.16 & 3.04 & 0.010 \\
\hline $\mathrm{FEV}_{1}$ (liters) & 1.07 & 0.59 & 1.92 & 0.814 \\
\hline Peak VO ${ }_{2}(\mathrm{ml} / \mathrm{min} / \mathrm{kg})$ & 0.90 & 0.86 & 0.95 & 0.000 \\
\hline
\end{tabular}

Models adjusted for age, gender, education level, socioeconomic status, hypertension, diabetes mellitus, dyslipidemia, obesity, smoking, lung

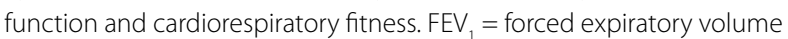
in the first second; $\mathrm{V}^{\prime} \mathrm{O}_{2}=$ oxygen uptake.
Table 4. Results from the logistic regression analysis between sedentary behavior assessed by accelerometers and factors associated to it (exposures)

\begin{tabular}{|c|c|c|c|c|}
\hline \multirow{2}{*}{ Exposures } & \multirow{2}{*}{$\begin{array}{l}\text { Odds } \\
\text { ratio }\end{array}$} & \multicolumn{2}{|c|}{$95 \%$ confidence interval } & \multirow{2}{*}{$\mathbf{P}$} \\
\hline & & Lower limit & Upper limit & \\
\hline Living in port area & 1.32 & 1.02 & 1.71 & 0.034 \\
\hline Age (years) & 1.03 & 1.01 & 1.15 & 0.022 \\
\hline Sex (male) & 0.73 & 0.62 & 0.87 & 0.000 \\
\hline \multicolumn{5}{|l|}{ Socioeconomic status } \\
\hline Low income & 1 & & & \\
\hline Moderate income & 1.24 & 1.01 & 1.51 & 0.032 \\
\hline High income & 1.40 & 1.12 & 1.75 & 0.002 \\
\hline $\begin{array}{l}\text { Completed secondary } \\
\text { educational level }\end{array}$ & 0.67 & 0.56 & 0.81 & 0.000 \\
\hline Hypertension & 0.84 & 0.66 & 1.17 & 0.175 \\
\hline Diabetes mellitus & 0.86 & 0.64 & 1.15 & 0.310 \\
\hline Dyslipidemia & 1.05 & 0.87 & 1.36 & 0.125 \\
\hline Obesity & 1.17 & 0.97 & 1.41 & 0.087 \\
\hline Smoking & 1.61 & 1.22 & 2.11 & 0.001 \\
\hline $\mathrm{FEV}_{1}$ (liters) & 0.95 & 0.61 & 1.47 & 0.837 \\
\hline Peak VO ${ }_{2}(\mathrm{ml} / \mathrm{min} / \mathrm{kg})$ & 1.01 & 0.97 & 1.04 & 0.525 \\
\hline
\end{tabular}

Sedentary behavior: categorized as high ( $\geq 10$ hours/day) or low ( $<10$ hours/day). Models adjusted for age, gender, education level, socioeconomic status, hypertension, diabetes mellitus, dyslipidemia, obesity, smoking, cardiorespiratory fitness and lung function. $F E V_{1}=$ forced expiratory volume in the first second; $\mathrm{V}^{\prime} \mathrm{O}_{2}=$ oxygen uptake. 
between higher socioeconomic status and higher amounts of sedentary behavior. It has been suggested that the associations between socioeconomic status and sedentary behavior present different directions in high-income countries, compared with low and middle-income countries, and that this varies according to the domain of sedentary behavior. Overall, the association between socioeconomic level and sedentary behavior is inverse. ${ }^{36}$ However, Mielke et al. ${ }^{36}$ observed that this relationship varies according to the income level of the country. In high-income countries, socioeconomic status presented an inverse association with sedentary behavior (effect size: 0.67 ; 95\% CI: $0.62-0.73$ ), whereas a positive relationship was observed in low to middle-income countries (effect size: 1.18; 95\% CI: 1.04-1.34). Unlike in high-income countries, in which all indicators of socioeconomic level were negatively associated with sedentary behavior, only resources showed a significant positive association in low to middle-income countries. Despite the significant relationship mentioned above, living in the port area remained a significant determinant of higher amounts of sedentary behavior.

Residents near port areas are exposed to increased levels of air pollution due to emissions of particulate matter derived from the exhaust fumes of trucks and ships, and as a result of mechanical processes of milling operations and the ensuing street dust suspensions. Very recent studies have reported on the influence of air pollution on decreased physical activity. ${ }^{37-39}$ In one of these studies, particulate matter and $\mathrm{O}_{3}$ levels were correlated with reduction in physical activity in daily life and the number of steps/day, among patients with chronic obstructive pulmonary disease (COPD).$^{38}$ Although air pollution was not assessed in our study, we believe that this in the port of Santos may partly explain the higher proportion of physically inactive people and larger amount of sedentary behavior among residents of the port area. In fact, a recent large study conducted in Brazil showed that the particulate matter monitoring in the city of Santos is poor and started only in 2011. Moreover, Santos only has two air-monitoring stations and is classified as having the sixth highest concentration of particulate matter in the state of São Paulo, Brazil. The average level of particulate matter in the metropolitan area of the city of Santos was $37.23 \mu \mathrm{g} / \mathrm{m}^{3}$ (annual mean) in 2011, which was significantly above the levels recommended by the World Health Organization. Despite the lack of assessment of particulate air pollution in the present study, it would be rational to suppose that environmental exposure to particulate matter may play a major role in the results presented here. ${ }^{19}$

Our results also showed that smoking was associated with physical inactivity and with greater amounts of sedentary behavior, independently. Previous results from the EPIMOV study ${ }^{40}$ reinforce the findings of the present study. We compared two groups of physically active individuals, one formed by smokers and the other by nonsmokers. Although they performed the same amount of moderate-to-vigorous physical activity, as assessed directly using triaxial accelerometers, and were matched regarding major confounders, the smokers performed higher amounts of sedentary physical activity and spent more time sitting and lying down per week. Like in the present study, other recent studies have reported an association between smoking and physical inactivity. ${ }^{41,42}$

As we expected, cardiorespiratory fitness was inversely associated with physical inactivity and living near the port did not alter the risk of physical inactivity. Ecological models for physical activity and sedentary behavior identified influences from several attributes, including individual components, the social environment, the physical environment and public policy. Some of the main barriers preventing physical activity are lack of motivation, awareness and time, and lack of structure for physical activity. ${ }^{43}$ People may have the necessary knowledge, skills, attitudes and motivation to be physically active, but if they do not have access to the necessary opportunities, they may be restricted or prohibited from being active. Building or enhancing facilities for physical activity can require a large amount of time and resources. Public health policies and intervention programs designed with a focus on increasing the level of physical activity and decreasing sedentary behavior are probably necessary for this region of Santos. Regarding the determinants of physical inactivity and sedentary

Table 5. Comparison between residents of the port area and people living in other areas regarding sedentary behaviors and the number of steps/day

\begin{tabular}{|c|c|c|c|c|c|c|}
\hline \multirow{2}{*}{ Variables } & \multicolumn{3}{|c|}{ People living in other areas } & \multicolumn{3}{|c|}{ Residents of port area } \\
\hline & Median & Percentile 5 & Percentile 95 & Median & Percentile 5 & Percentile 95 \\
\hline Sedentary physical activity (h/week)* & 70.73 & 40.22 & 152.22 & 79.50 & 42.31 & 160.07 \\
\hline Sedentary physical activity (\%/week)* & 75.30 & 61.30 & 88.70 & 77.40 & 64.90 & 90.87 \\
\hline Time standing (h/week)* & 37.87 & 17.20 & 65.44 & 33.68 & 12.41 & 57.52 \\
\hline Time standing (\%/week) ${ }^{*}$ & 21 & 9 & 34 & 20 & 7 & 34 \\
\hline Time spent lying down (h/week)* & 6.31 & 1.48 & 22.93 & 7.86 & 2.07 & 24.35 \\
\hline Time spent lying down (\%)* & 4 & 1 & 13 & 4 & 1 & 17 \\
\hline Number of steps/day* & 7,646 & 3,584 & 13,249 & 7,215 & 3,410 & 12,569 \\
\hline
\end{tabular}

${ }^{*} \mathrm{P}<0.05$ : residents of the port area versus residents of other neighborhoods. 
behavior, cohort studies are needed to investigate the causes of the associations of physical inactivity and greater amounts of sedentary behavior with living near the port area of Santos.

This study has limitations that need to be described. The crosssectional design did not allow us to establish any relationship between cause and effect. However, our objective was to evaluate the association between living near the port area of Santos and physical inactivity and sedentary behavior. We found that these associations were consistent. Our findings may guide new research questions towards identifying other determinants of physical inactivity and sedentary behavior relating to major ports.

\section{CONCLUSIONS}

Living near the largest port in Latin America, located in the city of Santos, Brazil, is associated with physical inactivity and sedentary behavior among adults, regardless of socioeconomic status, education level, cardiovascular risk, lung function or cardiorespiratory fitness. Whether this association is related to environmental exposure and/or to lack of equipment for physical activity in this region should be investigated in cohort studies.

\section{REFERENCES}

1. Torres RJ, Abessa DMS, Santos FC, et al. Effects of dredging operations on sediment quality: contaminant mobilization in dredged sediments from the Port of Santos, SP, Brazil. Journal of Soils and Sediments. 2009;9(5):42032. Available from: http://link.springer.com/article/10.1007/s11368-0090121-x. Accessed in 2016 (Nov 22).

2. Bezerra MGV, Rigotto RM, Pessoa VM, Silva FVE. Implicações do desenvolvimento econômico no trabalho, ambiente e saúde em comunidades portuárias no Ceará, Brasil [The implications of economic development on work, the environment and health in port communities in the State of Ceará, Brazil]. Ciên Saúde Coletiva. 2014;19(10):4023-30.

3. Grobar LM. The economic status of areas surrounding major U.S. container ports: evidence and policy issues. Growth and Change. 2008;39(3):497-516. Available from: http://onlinelibrary.wiley.com/ doi/10.1111/j.1468-2257.2008.00435.x/abstract. Accessed in 2016 (Nov 22).

4. Ripabelli G, Tamburro M, Sammarco ML, de Laurentiis G, Bianco A. Asthma prevalence and risk factors among children and adolescents living around an industrial area: a cross-sectional study. BMC Public Health. 2013;13:1038.

5. Yau PS, Lee SC, Cheng Y, et al. Contribution of ship emissions to the fine particulate in the community near an international port in Hong Kong. Atmospheric Research. 2013;124:61-72. Available from: http://www. sciencedirect.com/science/article/pii/S0169809513000033. Accessed in 2016 (Nov 22).

6. World Health Organization. Global Recommendation on Physical Activity for Health. Geneva: World Health Organization; 2010. Available from: http://apps.who.int/iris/bitstream/10665/44399/1/9789241599979_ eng.pdf. Accessed in 2016 (Nov 22).

7. Garber CE, Blissmer B, Deschenes MR, et al. American College of Sports Medicine position stand. Quantity and quality of exercise for developing and maintaining cardiorespiratory, musculoskeletal, and neuromotor fitness in apparently healthy adults: guidance for prescribing exercise. Med Sci Sports Exerc. 2011;43(7):1334-59.

8. Owen N, Leslie E, Salmon J, Fotheringham MJ. Environmental determinants of physical activity and sedentary behavior. Exerc Sport Sci Rev. 2000;28(4):153-8.

9. Rosenberg DE, Lee IM, Young DR, et al. Novel strategies for sedentary behavior research. Med Sci Sports Exerc. 2015;47(6):1311-5.

10. Gibbs BB, Hergenroeder AL, Katzmarzyk PT, Lee IM, Jakicic JM. Definition, measurement, and health risks associated with sedentary behavior. Med Sci Sports Exerc. 2015;47(6):1295-300.

11. Young DR, Reynolds K, Sidell M, et al. Effects of physical activity and sedentary time on the risk of heart failure. Circ Heart Fail. 2014;7(1):21-7.

12. Després JP. Physical Activity, Sedentary Behaviours, and Cardiovascular Health: When Will Cardiorespiratory Fitness Become a Vital Sign? Can J Cardiol. 2016;32(4):505-13.

13. Pandey A, Salahuddin U, Garg S, et al. Continuous Dose-Response Association Between Sedentary Time and Risk for Cardiovascular Disease: A Meta-analysis. JAMA Cardiol. 2016;1 (5):575-83.

14. Lee PH. Examining Non-Linear Associations between AccelerometerMeasured Physical Activity, Sedentary Behavior, and All-Cause Mortality Using Segmented Cox Regression. Front Physiol. 2016;7:272.

15. Owen N, Healy GN, Matthews CE, Dunstan DW. Too much sitting: the population health science of sedentary behavior. Exerc Sport Sci Rev. 2010;38(3):105-13.

16. Sperandio EF, Arantes RL, Matheus AC, et al. Distúrbio ventilatório restritivo sugerido por espirometria: associação com risco cardiovascular e nível de atividade física em adultos assintomáticos [Restrictive pattern on spirometry: association with cardiovascular risk and level of physical activity in asymptomatic adults]. J Bras Pneumol. 2016;42(1):22-8.

17. Sperandio EF, Arantes RL, da Silva RP, et al. Screening for physical inactivity among adults: the value of distance walked in the six-minute walk test. A cross-sectional diagnostic study. Sao Paulo Med J. 2016;134(1):56-62.

18. Giles-Corti B, Donovan RJ. The relative influence of individual, social and physical environment determinants of physical activity. Soc Sci Med. 2002;54(12):1793-812.

19. Vormittag EMPAA, Rodrigus CG, Miranda MJ, et al. Avaliação do impacto da poluição atmosférica no estado de São Paulo sob a visão da saúde. São Paulo: Instituto Saúde e Sustentabilidade; 2013. Available from: http://www.vereadornatalini.com.br/PDF/Documentofinaldapesqui sapadrao_2409FINALsitev1.pdf. Accessed in 2016 (Nov 22).

20. Thomas S, Reading J, Shephard RJ. Revision of the Physical Activity Readiness Questionnaire (PAR-Q). Can J Sport Sci. 1992;17(4):338-45.

21. Ferris BG. Epidemiology Standardization Project (American Thoracic Society). Am Rev Respir Dis. 1978;118(6 Pt 2):1-120. 
22. Thompson PD, Arena R, Riebe D, Pescatello LS; American College of Sports Medicine. ACSM's new preparticipation health screening recommendations from ACSM's guidelines for exercise testing and prescription, ninth edition. Curr Sports Med Rep. 2013;12(4):215-7.

23. Santos JDP, Silveira DV, Oliveira DF, Caiaffa WT. Instrumentos para avaliação do tabagismo: uma revisão sistemática [Instruments used to evaluate smoking habits: a systematic review]. Ciên Saúde Coletiva. 2011;16(12):4707-20.

24. Lohman TG, Roache AF, Martorell R. Anthropometric standardization reference manual. Champaign: Human Kinetics Books; 1991.

25. Miller MR, Hankinson J, Brusasco V, et al. Standardisation of spirometry. Eur Respir J. 2005;26(2):319-38.

26. Pereira CAC, Neder JA. Diretrizes para testes de função pulmonar. Jornal Brasileiro de Pneumologia. 2002;28(Supl 3):s1-s238. Available from: http://www.jornaldepneumologia.com.br/detalhe_suplemento. asp?id=45. Accessed in 2016 (Nov 22).

27. Hansen JE, Sue DY, Wasserman K. Predicted values for clinical exercise testing. Am Rev Respir Dis. 1984;129(2 Pt 2):S49-55.

28. Porszasz J, Casaburi R, Somfay A, Woodhouse LJ, Whipp BJ. A treadmill ramp protocol using simultaneous changes in speed and grade. Med Sci Sports Exerc. 2003;35(9):1596-603.

29. Troiano RP, Berrigan D, Dodd KW, et al. Physical activity in the United States measured by accelerometer. Med Sci Sports Exerc. 2008;40(1):181-8.

30. Brooks AG, Gunn SM, Withers RT, Gore CJ, Plummer JL. Predicting walking METs and energy expenditure from speed or accelerometry. Med Sci Sports Exerc. 2005;37(7):1216-23.

31. Trost SG, Way R, Okely AD. Predictive validity of three ActiGraph energy expenditure equations for children. Med Sci Sports Exerc. 2006;38(2):380-7.

32. Matthew CE. Calibration of accelerometer output for adults. Med Sci Sports Exerc. 2005;37(11 Suppl):S512-22.

33. American College of Sports Medicine. ACSM's guidelines for exercise testing and prescription. $8^{\text {th }}$ ed. Philadelphia: Lippincott Williams \& Wilkins; 2009.

34. American College of Sports Medicine Position Stand. The recommended quantity and quality of exercise for developing and maintaining cardiorespiratory and muscular fitness, and flexibility in healthy adults. Med Sci Sports Exerc. 1998;30(6):975-91.

35. Lindström M, Hanson BS, Ostergren PO. Socioeconomic differences in leisure-time physical activity: the role of social participation and social capital in shaping health related behaviour. Soc Sci Med. 2001;52(3):441-51.

36. Mielke Gl, Brown WJ, Nunes BP, Silva IC, Hallal PC. Socioeconomic Correlates of Sedentary Behavior in Adolescents: Systematic Review and Meta-Analysis. Sports Med. 2016. [Epub ahead of print].

37. Roberts JD, Voss JD, Knight B. The association of ambient air pollution and physical inactivity in the United States. PLoS One. 2014;9(3):e90143.

38. Alahmari AD, Mackay AJ, Patel AR, et al. Influence of weather and atmospheric pollution on physical activity in patients with COPD. Respir Res. 2015;16:71.
39. Li F, Liu Y, Lü J, Liang L, Harmer P. Ambient air pollution in China poses a multifaceted health threat to outdoor physical activity. J Epidemiol Community Health. 2015;69(3):201-4.

40. Sperandio E, Lauria V, Matheus A, et al. Cardiorespiratory fitness and peripheral muscle function in physically active adult smokers. European Respiratory Journal. 2014;44(Suppl 58):P4891. Available from: http://erj.ersjournals.com/content/44/Suppl_58/P4891. Accessed in 2016 (Nov 22)

41. Holahan CK, Holahan CJ, Li X. Living With a Smoker and Physical Inactivity: An Unexplored Health Behavior Pathway. Am J Health Promot. 2015;30(1):19-21.

42. Papathanasiou G, Papandreou M, Galanos A, et al. Smoking and physical activity interrelations in health science students. Is smoking associated with physical inactivity in young adults? Hellenic J Cardiol. 2012;53(1):17-25.

43. Mabry RM, Al-Busaidi ZQ, Reeves MM, Owen N, Eakin EG. Addressing physical inactivity in Omani adults: perceptions of public health managers. Public Health Nutr. 2014;17(3):674-81.

Sources of funding: This study received financial support in the form of a research grant from the São Paulo Research Foundation (FAPESP), in the state of São Paulo, Brazil, grant no. 2011/07282-6

Conflict of interest: The authors declare that they did not have any conflicts of interest regarding this paper

Date of first submission: June 16, 2016

Last received: September 28, 2016

Accepted: October 12, 2016

\section{Address for correspondence:}

Evandro Fornias Sperandio

Departamento de Ciências do Movimento Humano

Universidade Federal de São Paulo (Unifesp)

Av. Ana Costa, 95

Vila Matias - Santos (SP) - Brasil

CEP 11060-001

Tel./Fax. (+55 13) 3261-3324

E-mail: evandrosperandio@yahoo.com 